\title{
A Design of an Innovative Thematic Textbook Based on the Model of the Integrated Religious Characters
}

\author{
Estuhono $^{1}$, Rusdinal ${ }^{2}$, Nurhijrah Gistituati ${ }^{2}$ \\ 1. Doctoral Program Universitas Negeri Padang, Indonesia \\ 2. Universitas Negeri Padang, Indonesia
}

How to cite this paper: Estuhono, Rusdinal, Gistituati, N. (2018). A Design of an Innovative Thematic Textbook Based on the Model of the Integrated Religious Characters. The Educational Review, USA, 2(4), 238-244. http://dx.doi.org/10.26855/er.2018.04.001

Corresponding author: Estuhono, Doctoral Program Universitas Negeri Padang, Indonesia.

\begin{abstract}
This research was conducted based on the importance of innovative textbook development that can build student's religious character. It needs strategic ways to build religious character comprehensively through learning to every student. The purpose of this study is to produce innovative textbook thematic-based model with religious character integrated. This research is designed in form of development research. The development of innovative textbook thematic-based model with religious character integrated uses 4-D models, which consisted of four phases: define, design, develop and disseminate. The data are collected by using a validation sheet of textbooks, practicality questionnaires and instrument of effectiveness. The results of the define phase find that Islamic Plus elementary school in Dharmasraya was used 2013 curriculum with thematic-based model. An analysis showed that the students of primary school (7-11 years) were at the stage of concrete operations that have been able to think of a less logical way to thinking more logically. Analysis of the material obtained facts, concepts, principles and procedures of learning materials that integrate the religious character. Results of research on the design phase were obtained draft text books based innovative textbook thematic-based on the model o religious character integrated.
\end{abstract}

Keywords

Development, Textbooks, Thematic, Character, Religious

\section{Introduction}

It stated in the Law of the Republic of Indonesia number 20 in 2003, "National education functions were to develop and form the character and civilization of a dignified nation in order to educate the nation's life, aims for the development of potential students to become human beings who believe and fear God Almighty, noble, healthy, knowledgeable, capable, creative, independent, and become a democratic and responsible citizen ". Starting from the formulation of the function and the purpose of national education was known that the development of national education to seek the formation of high quality Indonesian human beings and to form a good human character. One effort that has been made by the government to support the realization of the ideals and goals of national education was convinced by making improvements to the curriculum to the implementation of the Curriculum 2013 oriented in character education. Implementation Curriculum 2013 especially in elementary school was designed using thematic learning concept.

There are some concepts definition of thematics. Thematic learning is organized in a theme or can be called thematic. Charles (2015: 5) argues that a thematic approach is an attempt to integrate knowledge, skills and values of learning and 
creative thinking using themes. In other words thematic learning is a learning that uses the theme in relating some subjects so as to provide meaningful experiences for learners. Thematic learning is meaningful because in thematic learning, learners will understand the concepts learned through direct experience and connect it with other concepts that have been understood. This approach departs from the Gestalt and Piaget learning theories that emphasize that learning should be meaningful and oriented to the needs and development of learners. Thematic learning approach emphasizes the application of the concept of learning while doing something (learning by doing).

Furthermore, Charles in (2015: 6) also states that themes in thematic learning are central to be developed. The theme is expected to provide many advantages, including: 1) learners easily focus on a particular theme, 2) Learners are able to learn knowledge and develop a variety of basic competencies between subjects in the same theme; 3) the understanding of the subject matter is more profound and memorable; 4) basic competencies can be better developed by linking other subjects with the learners' personal experience; 5) Learners are more able to feel the benefits and meaning of learning because the material presented in the context of a clear theme; 6) Learners are more passionate about learning because they can communicate in real situations, to develop a capability in one subject while studying other subjects; 7) the teacher can save time because the subjects presented thematically can be prepared at once and given in two or three meetings, the remaining time can be used for remedial, stabilization, or enrichment activities.

The fact that occurred in the field, the implementation of thematic pemenang not fully in accordance with the demands of the curriculum is to pay attention to the characteristics of the integrative material and characteristics of learners. So far the maximum effort of government and educational unit in order to integrate the learning materials with the religious character of learners. Another fundamental issue found in the field is the unavailability of teaching materials especially on the theme of myself which is integrated religious character. The available teaching materials are still limited to textbooks of students whose discussion has not yet been integrated with the religious character. This is suspected the role of teachers who are still not maximized in developing teaching materials that support the implementation of integrative thematic learning that integrates learning materials with character values, especially religious characters.

One of the efforts that can be done is through the development of integrative thematic teaching materials by integrating the values of religious characters into learning materials covered in a learning theme. The goal is that learners understand the values of religious characters so that expectations can be implemented in their daily lives. Of course this must be in accordance with thematic instructional guidelines possessed by teachers. If these themes are not related to the values of a universal religious character, then the themes will keep learners away from the values of character, especially religious characters

As it was quoted from another source, Kunandar (2007: 23) states that thematic learning has advantages namely: 1) Fun because depart from the interests and needs of learners; 2) Provide experience and teaching-learning activities relevant to the level of development and needs of learners; 3) Learning outcomes can last long because they are more memorable and meaningful; 4) Develop the thinking skills of the participants in accordance with the problems faced; 5) Growing social skills through cooperation; 6) Have an attitude of tolerance, communication and responsive to the ideas of others; 7) Presenting activities that are real in accordance with the problems faced in the environment of learners. In line with that, Hamzah (2015: 52) discloses the development of integrative teaching materials is an effort to bring value-based science as an effort to increase and awaken learners' awareness from aspects of intellectual, emotional and spiritual. This is done so that the impression of general learning materials that have not contributed moral education and morals to improve faith and piety learners

As a strategic effort to overcome these problems, researchers try to develop teaching materials in the form of innovative textbooks based on thematic learning model intergrated religious characters. Textbooks are handbooks for subjects 
written and composed by relevant field experts and fulfill textbook norms and published officially and disseminated (Dirjendikti, 2009: 7). In addition, textbooks are guidelines that will direct the activities of teachers in the learning process, as well as a substance of competence that should be taught to learners. The substance of the textbook contains an element of scientific authority, expertise, intellectual and scientific quality of the author in connection with his discoveries.

The development of innovative textbooks based on the thematic model of terintegerasi religious character refers to Permendiknas Number 41 Year 2007. Textbooks are designed through curriculum analysis, material analysis especially the theme of myself, and analysis of the characteristics of learners. Preparation of textbooks conducted in a systematic, clear, specific and provide opportunities for students to develop creative thinking. In addition, textbooks specifically accommodate the values of religious characters that are integrated with learning materials especially on the theme of myself. Based on the above background it is important to do an innovative textbook design based on thematic learning model integrated religious character on my theme in class 1 Islamic Elementary Plus Dharmasraya School.

\section{Research Methods}

Based on the research step that will be done, this research type is research development. Research and development method is a research method used to produce a particular product, and test the effectiveness of the product (Sugiyono: 2010: 297). This innovative textbook development model uses 4D model which starts from define, design, development,

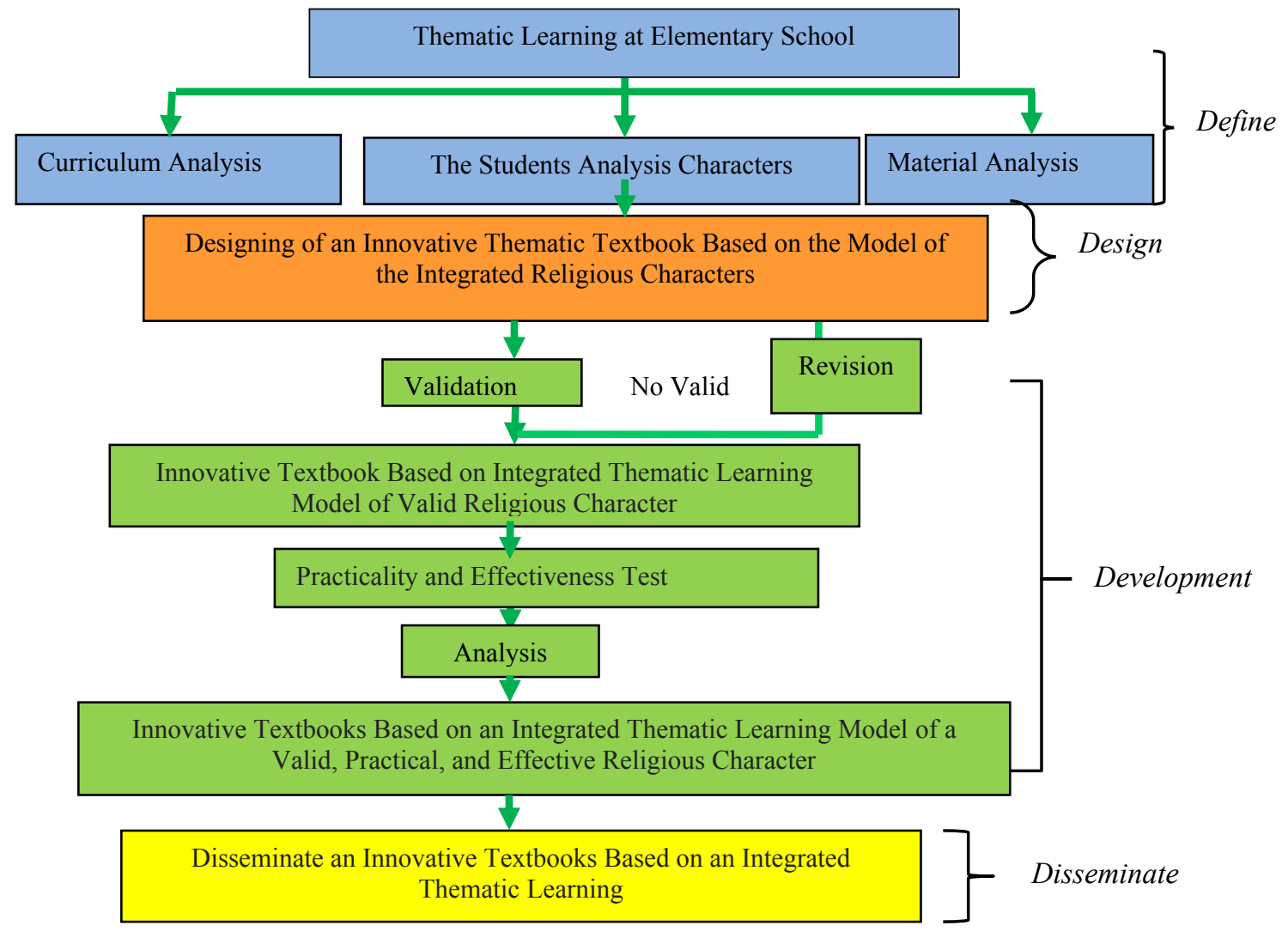

Figure 1. The Steps model of development of 4-D learning tools (Trianto, 2009: 190). 
and disseminate. The development stage of innovative textbooks based on thematic learning model integrated religious character is described as shown in Figure 1.

The subject of the experiment on developing innovative textbooks based on the thematic model of integrated religious character is the students of Islamic Elementary School Plus Dharmasraya. Instrument of data collection in this research used validation sheet, questionnaire of practicality and instrument of textbook effectiveness. While the data analysis techniques use certain formulations which are then converted into Likert scale 1- 4 to determine the percentage level of validity, practicality and effectiveness of developed textbooks.

In this research, new researchers come to the design stage. The define stage is done curriculum analysis, characteristic analysis of learners, and material analysis. Design stage is done by designing innovative textbook based on thematic model of integrated learning of religious character.

\section{Findings and Discussion}

\subsection{Definition Stage (Define)}

The purpose of defining stage is to define the requirements needed in the lesson. This stage had analyzed three aspects, namely curriculum analysis, characteristic analysis of learners, and material analysis. The following will be discussed in each aspect mentioned above.

\subsubsection{Curriculum Analysis}

Based on the curriculum analysis it is known that the curriculum used at the Dharmasraya and Islamic Elementary School plus uses the 2013 Curriculum. The implementation of the 2013 curriculum uses learning concepts that focus more on the process than on the results. In the process, there are 3 things that must be obtained by students on each learning theme, namely attitude, skills, and knowledge. Through these three targets, students are expected not only well known but also have the skills that will certainly be needed when students start involve in the world of work and society, and have the attitude of sholih towards others and their environment. Based on Permendiknas No. 22 of 2006 about the content standards obtained the theme of learning in this study is the theme of myself which is divided into four subtheme covering subtheme, I and new friends, my body, how do I take care of my body, and I'm special. Based on the Ministerial Regulation No. 41 of 2007 on the standard process set by the government for basic education units include learning process planning, implementation of learning process, assessment of learning outcomes, and supervision of the learning process.

\subsubsection{Characteristic Analysis of Learners}

An analysis of the characteristics of learners using AUM (Screening Tool Problem) PTSDL and obtained prerequisite mastery of material (P) learners (Prayitno, 1997: 24). In general, the level of mastery of the initial material as a further material prerequisite is still not optimal and the learning motivation of the learners is also still low, from the learning skill (T) the students have not been trained to improve the problem solving skills to get the important concepts, from the facilities and infrastructure ) for teaching materials that are not used maximally the integrity of religious character values in learning, self (D) age of elementary school students (7-11 years) are at concrete operational stage that has been able to think from less logical to more logical thinking which is at the formal stage of operations so that it is able to think abstractly and social environment (L) there is a tendency to be more individualistic and less interactive in the learning process. 
PPKn Accepting the diversity of individual characteristics (religious, ethnic, physical, psychic) as God's gift (KI-1) Demonstrate good behavior (honest, disciplined, responsible, polite, caring / affectionate, and confident) in interacting with family, friends, and teachers as embodiment of Pancasila values and morals (KI-2) Recognizing the diversity of individual characteristics through observations at home and school (KI-3) Knowing the rules and rules that apply in everyday life at home and school (KI-3, KD2).

\section{NDONESIAN}

Listening to the use of good Indonesian to pray (according to the religion it embraces) at school and at home. (KI-1, KD-2).

Praying a prayer with good pronunciation (KI-1, KD-3).

Demonstrate good and polite behavior in listening and speaking at the time of introducing identity, conversing with family, teachers, and friends (KI2, KD-1).

Greet and congratulate, thank you or apologize according to the context (KI-2, KD-2).

Communicate verbally with others using information about personal data, body parts and body needs, environment and healthy lifestyle, surrounding environment, fruit, plants, and cuisine (KI-4, KD-1).

Spontaneous speech about self (KI-4, KD-3).

- Observing about self, living things and things around and telling others (KI-4, KD-5).

- Apply the way of reading (beginning) in the right way (how to sit, the distance of the eyes and the book, how to hold the book, how to turn the page, choose a place with bright light) (KI-4, KD-8).

- Apply proper way of starting the paper (how to sit, how to hold a pencil, how to put the book, the distance of the eyes and the book, and to choose a place with bright light) (KI-4, KD-9).

\section{NDONESIAN}

Listening to the use of good Indonesian to pray (according to the religion it embraces) at school and at home. (KI-1, KD-2).

Praying a prayer with good pronunciation (KI-1, KD-3).

Demonstrate good and polite behavior in listening and speaking at the time of introducing identity, conversing with family, teachers, and friends (KI-2, KD-1).

Greet and congratulate, thank you or apologize according to the context (KI-2, KD-2).

Communicate verbally with others using information about personal data, body parts and body needs, environment and healthy lifestyle, surrounding environment, fruit, plants, and cuisine (KI-4, KD-1).

Spontaneous speech about self (KI-4, KD$3)$.

Observing about self, living things and things around and telling others (KI-4, KD5).

Apply the way of reading (beginning) in the right way (how to sit, the distance of the eyes and the book, how to hold the book, how to turn the pages of a book, choose a place with bright light) (KI-4, KD-8).

Apply how to write.

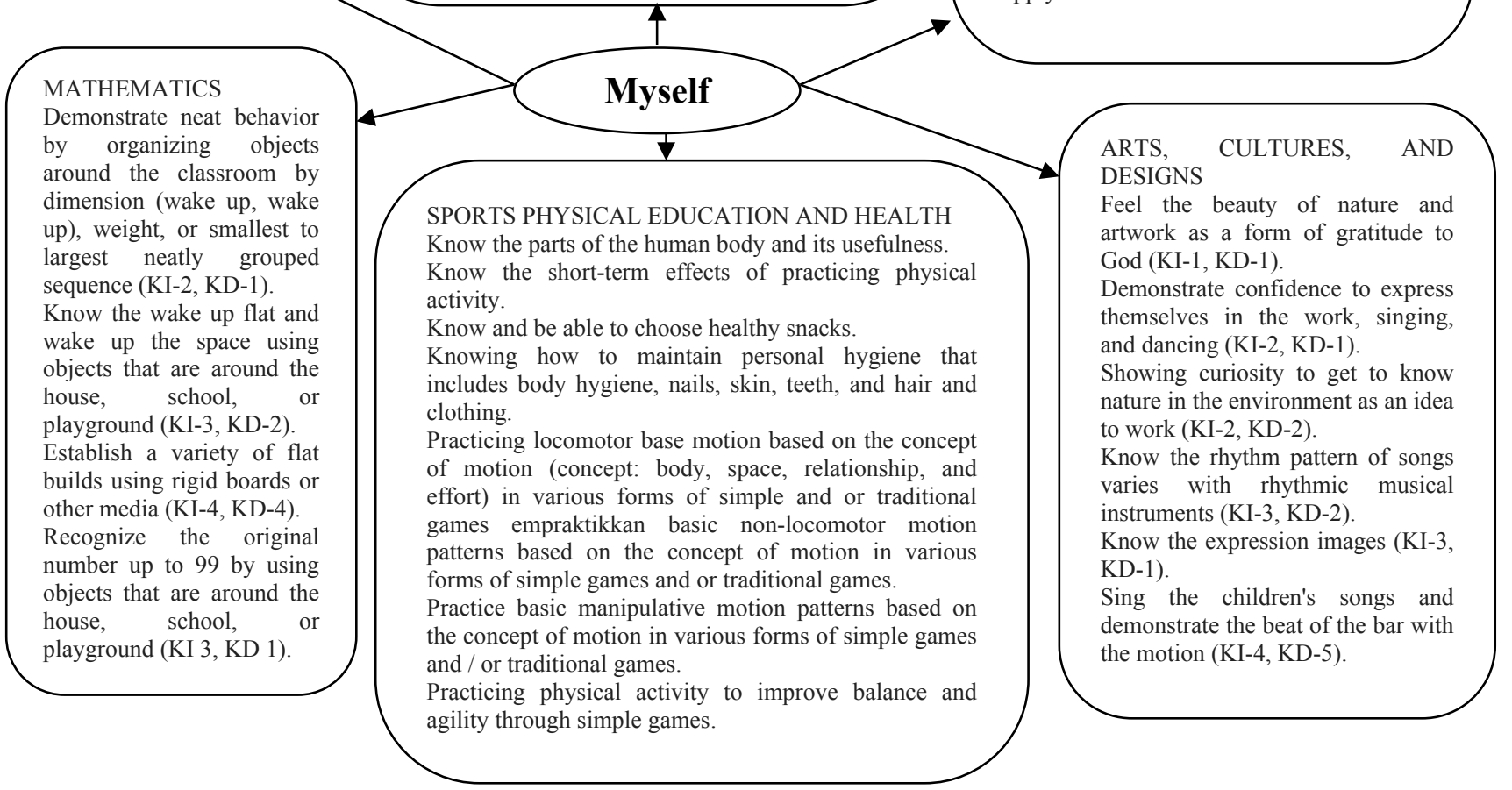

Figure 2. Basic competence network on theme. 


\subsubsection{Material Analysis}

Material analysis is based on the Ministry of National Education (2008: 13) on the guidance of the development of learning materials obtained material on the theme of myself can be formulated as in Figure 2.

\subsection{Stage Design (Design)}

The design stage is the second stage in the development of innovative textbooks based on thematic learning model integrated religious characters on my theme in grade 1 primary school. The product of teaching materials produced in this research is in the form of student textbooks. The textbook design uses a thematic learning model by making innovations in the form of integrating the religious character in every lesson learned.

\section{Conclusion}

Based on the research that has been done can be concluded several important points as follows:

1) The results of the define phase study on the curriculum analysis obtained curriculum developed in Islamic Elementary School Plus Dharmasraya using the 2013 based curriculum of thematic learning model.

2) Student analysis found that elementary school students (7-11 years) are at concrete operational stages that have been able to think from less logical to more logical thinking.

3) Material analysis obtained facts, concepts, principles and procedures of learning materials especially the theme of myself that is integrated with the value of religious character.

4) The results of the research at the design stage obtained the design of innovative textbooks based on thematic learning model terintegerasi religious characters.

\section{Appreciation}

The authors would like to thank all parties who have supported the implementation of this research, especially the Faculty of Teacher Training and Education Universitas Dharmas Indonesia.

\section{References}

Charles. (2015). Pengembangan Bahan Ajar Tematik-Integralistik Berbasis Agama (Makalah disampai dalam Acara ISTE 2015 UIN Suska Pekan Baru tanggal 21-22 November 2015).

Depdiknas. (2006). Kurikulum Tingkat Satuan Pendidikan. Jakarta: Direktorat Jenderal Manajemen Pendidikan Dasar dan Menengah.

Depdiknas. (2011). Pedoman Pelaksanaan Pendidikan Karakter. Jakarta: Kementrian Pendidikan Nasional.

Dirjendikti. (2009). Pedoman Angka Kredit Dosen. Jakarta: Dirjendikti.

Hajar, I. (2013). Panduan Lengkap Kurikulum Tematik untuk SD/MI, Jogjakarta: Diva Press.

Hamzah, F. (2015). Studi Pengembangan Modul Pembelajaran IPA Berbasis Integrasi Islam-Sains Pada Pokok Bahasan Sistem Reproduksi Kelas IX Madrasah Tsanawiyah. Jurnal Pendidikan Islam, 1 (1), 41-56.

Kemendikbud. (2013). Buku Tematik Terpadu Kurikulum 2013. Jakarta:Media Kreatif.

Kunandar. (2007). Guru Profesional: Implementasi Kurikulum Tingkat Satuan Pendidikan (KTSP) da Persiapan Menghadapi Sertifikasi Guru. Jakarta: PT Raja Grafindo Persada.

Peraturan Pemerintah No. 19 Tahun. (2005). Tentang Standar Nasional Pendidikan. 2005. Jakarta: BSNP.

Permendiknas Nomor 41 Tahun. (2007). Tentang Standar Proses.2007 Jakarta: BSNP.

Prayitno, dkk. (1997). Pedoman AUM PTSDL Format 2: Siswa SLTA. Padang: Program Studi Bimbingan Konseling Jurusan Psikologi Pendidikan dan Bimbingan FIP IKIP Padang.

Sugiyono.(2010). Metode Penelitian Pengembangan, R\&D. Jakarta: Gramedia.

Trianto. (2010). Model Pembelajaran Terpadu. Jakarta: Bumi Aksara. 
Undang Undang No.20 tahun. (2003). Tentang Sistem Pendidikan Nasional. Jakarta. Depdiknas.

Wina, S. (2008). Srategi Pembelajaran Berorientasi Standar Proses Pendidikan. Jakarta: Prenada Media Grup. 